\title{
Kent Kıyılarının ve Suyun Kamusal Sanatla Dönüşümü
}

\author{
Cemre Kılınç $^{1 *(D)}$, Mehmet İnceoğlu ${ }^{\text {iD }}$, Sema Balçık \\ ${ }^{1}$ Bingöl Üniversitesi, Mimarlık Bölümü, Bingöl, Türkiye \\ ${ }^{2}$ Eskişehir Teknik Üniversitesi, Mimarlık Bölümü, Eskişehir, Türkiye \\ ${ }^{3}$ Eskişehir Teknik Üniversitesi, Mimarlık Bölümü, Eskişehir, Türkiye \\ *ckilinc@bingol.edu.tr
}

\section{Özet}

Kamusal sanat toplumu oluşturan birbirinden farklı bireyleri bir araya getirerek, fikirlerin, istek ve intiyaçların ifade edilebileceğı bir alan sunmaktadır. Bu anlamda kentsel mekânlarda yer alması toplum yaşamına katkı sağlamaktadır. Kamusal sanat ürünleri günümüzde kentsel mekânların vazgeçilmezi olmaya başlamıştır. Geçici ya da kalıcı olarak yerleştikleri andan itibaren kamusal alana getirdiği dinamizm mekâna yeni bir soluk olmaktadır. Özellikle son yıllarda kıyı ile ilişki kuran, su ile temas eden, ona dokunan geçici kamusal sanat ürünleri yaygınlaşmaktadır. Bu çalışmada yumuşak bir zemin olarak suyun ve kent kıyılarının kamusal sanatla olan temasını içeren örnekler kentsel kalite parametreleri doğrultusunda irdelenmiş ve AntalyaKonyaaltı Sahili çerçevesinde yapılan kent mobilyaları şeklindeki kamusal sanat ürünleri incelenerek alana dair önerilerde bulunulmuştur.

Anahtar Kelimeler: Kamusal Sanat, Kıyı, Su Ögesi, Kentsel Mekân ve Sanat

\section{The Transformation of Water and Urban Coast with Public Art}

\begin{abstract}
Public art offers a space where ideas, desires and needs can be expressed by bringing together the different individuals that make up the society. In this sense, taking place in urban spaces contributes to community life. Public art products have become indispensable for urban spaces today. The dynamism it brings to the public space from the moment they settle temporarily or permanently is a breath of fresh air to the space. Especially in recent years, temporary public art products that have contact with the coast, touch and touch the water are becoming widespread. In this study, the examples containing the contact of water and city coasts with public art as a soft ground were examined in line with the urban quality parameters and public art products in the form of urban furniture made within the framework of Antalya-Konyaaltı Beach were examined and suggestions were made regarding the area.
\end{abstract}

Keywords: Public Art, Coast, Water Element, Urban Space and Art 


\section{GiRiş}

Kamusal sanat en basit haliyle halkın kolaylıkla görebileceği, herkes tarafından ulaşılabilir mekânlarda yapılan sanat olarak tanımlanabilir [1]. Günümüzde kamusal sanata olan ilgi giderek artmakta ve toplumsal bir gereksinime dönüşmektedir. 21. Yüzyıl ile gelişen teknoloji sayesinde sanatsal faaliyetler çeşitlenerek kamusal mekânın vazgeçilmezi olmaya başlamıştır. Bireyin günlük hayatta karşılaştığı geçici kamusal sanat ürünleri kanıksadıkları mekâna yeni bir soluk ve dinamizm getirmektedir. Bu bakımdan kamusal sanat ürünleri bir kamusal mekânı yeniden tanımlama gücünü elinde bulundurmaları bakımından oldukça önemlidir.

Sanatın yeni düşünce ve uygulamaların denendiği bir laboratuvar oluşu [2] ve sürecin deneyimlenebildiği, test edilebildiği bir alan olarak kamusal mekânlarda, 2000'li yıllar itibariyle sıkça görmeye başladığımız pavyon, enstalasyon, kent mobilyaları gibi kamusal sanat ürünleri mekâna getirdiği canlılık, dinamizm ve estetikle dikkat çekmekte ve mekânın kalitesini arttırmaktadır. Mekânsal kalite, Rapoport tarafından tasarımda fark edilen, göze çarpan farklılıklar olarak tanımlanmıştır [3]. Estetik ve mekâna ait işlevsel değerler doğrultusunda mekân kalitesi üzerine pek çok çalışma yapılmıştır. Sherwin Greene [4], tasarımla ilişkili mekân kalitesini sınıflandırırken işlev, düzen, kimlik, cazibe/çekim parametreleri olduğunu ifade etmiştir. Kamusal sanat ürünlerinin, konumlandığı kent mekânlarının kalitesini artırırken o mekâna kimi zaman yeni bir işlev ve düzen kazandırdığı, kimi zaman o mekânı yeniden tanımlama gücüyle yeni bir kimlik kazandırdığı, kimi zamansa o mekânı bir cazibe/çekim noktası haline getirdiğini ifade etmek yanlış olmayacaktır. Çalışmada nitel araştırma yönteminden yararlanılarak çalışmanın kapsamını oluşturan kent kıyılarında ve su üzerinde bulunan beş farklı kamusal sanat çalışması derlenmiştir. Bu örneklerin seçiminde bulundukları yerle ilişkileri, işlevleri, su ile kurdukları ilişki ve mekân kalitesine etkileri belirleyici olmuştur. Bu doğrultuda çalışmada dünya üzerinde yer alan kent kıyıları ve su ile ilişsili kamusal sanat ürünlerinin kentsel mekân kalite parametreleri üzerinden irdelenerek Antalya Konyaaltı Sahili'nin kamusal sanat ürünleri üzerinden incelenmesi ve çeşitli önerilerde bulunulması amaçlanmıştır.

\section{KAMUSAL SANAT ÜRÜNLERI: KENT KIYILARI VE SU ÖGESI ÍLE İLIŞKISİ}

En genel anlamıyla sanat, "Pratik hatta mekânik bir yeteneğin, yaratıcılıkla yoğrulup ortaya sıra dıșı bir eser halinde dökülmesi ve kişinin içindekileri ruh, zekâ, duygu ve beden harmonisiyle dışarıya yansıtması olarak ifade edilmektedir [5],". Sanat öznel gerçekliği nesnelleştiren aynı zamanda doğaya ait dışsal deneyimleri de öznelleştiren bir kavramdır [6]. Sanat, sanatçının bir dizi iletişimsel etkiyi kendi yarattığı özgür kompozisyonu her izleyicinin kendine göre anlamlandıracağ 1 şekilde düzenleme uğraşının son ürünüdür [7] gibi tanımlar da mevcuttur. Sanatçının, dışsal deneyimleri geniş ve herkesin erişebileceği bir izleyici kitlesine sunmasıyla ve kamusal mekânda sanat-tasarımın bir araya gelmesiyle oluşan bu dişa vurum kamusal sanat olarak karşımıza çıkmaktadır.

Kamusal sanat toplumun farklı kesimlerinin buluştuğu, düşüncelerin, arzu ve ihtiyaçların ifade edildiği bir alandır. İzleyici-mekân-sanat ürünü arasında her zaman karşılıklı ilişki bulunmaktadır [8]. Sanat arenası kamusal alandır ve iletişim kurulabilecek bir platform isteğiyle oluşturulur [9]. Bu iletişim kamusal açık alanlarda mevcut mekâna heyecan katması açısından mekâna kimlik kazandırır [10]. Sanatçılar, mimarlar, kentsel tasarımcılar, plancılar, sosyologlar yani toplumun ayrı kesimleri arasındaki paylaşımlar yere ait olanın ortaya çıkarılmasını sağlar [11]. İster maddesel ister sanal ya da hayali olsun sanatsal bir mekân yaratmak, kimlik oluşumuna katkı sağlaması, yere özgü olanı açığa çıkarması, toplumun bir yansımasını yaratması ve kamu mekânının kullanımını kamusal mekândaki davranış biçimlerini anlamlandırması açısından oldukça önemlidir [12]. Bir temsil biçimi olarak sanat birey ile dünya arasında bir mekâna yerleşerek bireyin çevresine bakışını, algılayışını değiştirebilir. 
Kıyılar tarih boyunca seçkin mekânlar olmuşlardır. Kara parçası ile su arasında bir ara mekân oluşturarak eșik görevi gören kıyılar aynı zamanda toplumların da ihtiyacı olmuştur [13]. Kıyıların su öğesi ile kurduğu ilişkiler sadece denizler ile sınırlı olmamakla beraber nehir, göl, akarsu gibi alanlarda da değişkenlik gösterebilmektedir. Sert zemin olan kıyılarla yumuşak zemin olarak nitelendirilebilen su ögeleri kimi zaman farklı kullanımlara şahit olmaktadır. Kamusal sanat ise bu kullanımların başında gelmektedir. Kamusal sanat 21. Yüzyıl ile başlayan süreçte çok farklı mekânlarda sergilenmeye başlamıştır. Kent meydanından, kırsal bir araziye, sokaktan meydana, kıyılardan su öğesinin üzerine ve hatta havada dahi çeşitlenerek sergilenmeye başlayan pavyon, enstalasyon ve kent mobilyaları konumlandıkları yerde bireylerin kanıksadıkları mekâna farklı bakış açılarıyla bakarak orayı yeniden keşfetmesini sağlamaktadır. Aynı zamanda kamusal sanat, kısa süreli olarak "hoşa giden biçimler yaratma gayesidir [14]". Bu anlamda geçici sanat ürünlerindeki zamansallık durumu kentlilerin ilgisini, merakını arttırarak günlük yaşantıyı ve kent mekânlarının kullanımını zenginleştirmektedir. Bu doğrultuda literatür çalışması kapsamında su ögesi üzerinde ve kent kıyılarında yer alan dünya örneklerinden "The Floating Piers" Enstalasyonu (İtalya-2016), "1/4 Mile Arc" Enstalasyonu (Amerika-2017), "Three Matrix" Pavyonu (Amerika- 2017), "Triennale Brugge" Pavyonu (Hollanda-2018) ve "Russian Creativity Week" Pavyonu (Rusya-2020) incelenmiştir. Bu örnekler Sherwin Greene [4] tarafindan belirlenen işlev, düzen, kimlik, cazibe/çekim kalite parametreleri çerçevesinde değerlendirilmişlerdir.

\section{1 “The Floating Piers” (Yüzer İskele) Enstalasyonu, İtalya- 2016}

Tasarım aşaması aslında 1970 yılından itibaren başlamış ve sonrasında devam etmiş olan Christo-Jeanne Claude tasarımı olan enstalasyon 2016 yılında İtalya' da bir yumuşak zemin olarak Iseo Gölü'nün yüzeyinde sergilenmiştir. Gölün kıyısından başlayıp denizin üstüne taşan tasarım, adaları su üzerine kurulan platform ile birbirine bağlamıştır. San Paolo adasına doğru yürüyen ziyaretçiler gölü çevreleyen dağları, fark edilmeyen açıları deneyimleme fırsatı yakalayarak göle olan bakış açılarını yenilemiş ve eşsiz anlara şahit olmuşlardır.
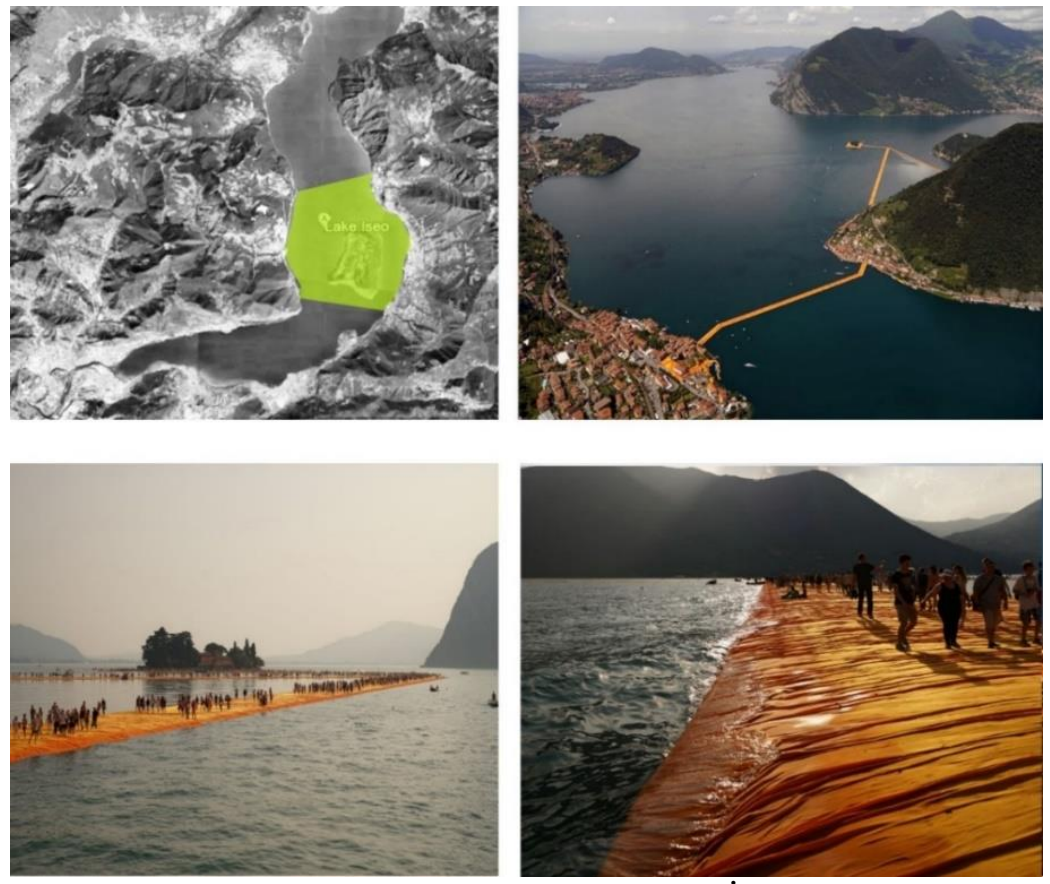

Şekil 1. 'The Floating Piers' Enstalasyonu, İtalya, 2016 [15]. 
Tasarım gece gündüz 24 saat boyunca herkesin kullanımına açık bir şekilde ziyaretçilere suyun üstünde yürüme deneyimi yaşatmıştır. Tasarımın halka açık olmasıyla ilgili Christo, "Bilet yok, rezervasyon yok ve mal sahibi yoktu. 'Yüzer İskele' sokağın bir uzantısıydı ve herkese aitti [16]." diyerek enstalasyonun kamusallığını öne çıkarmıștır. Olușturulan iskele 3 kilometre uzunluğunda, 16 metre genișliğinde ve eğimli kenarları yaklaşık 35 santimetre yüksekliğindedir. Platform sarı-turuncu bir kumaşla kaplanmıștır. Tasarımın kıyıyla kurmuş olduğu ilişkide kumaşın sadece deniz üstündeki platform üzerinde eğil,uzantısının göl kıyısındaki sokakların içlerine sızarak $1.5 \mathrm{~km}$ boyunca devam etmiş olması sürekliliği sağlayarak kentte bir bütünlük yaratmıştır [17].
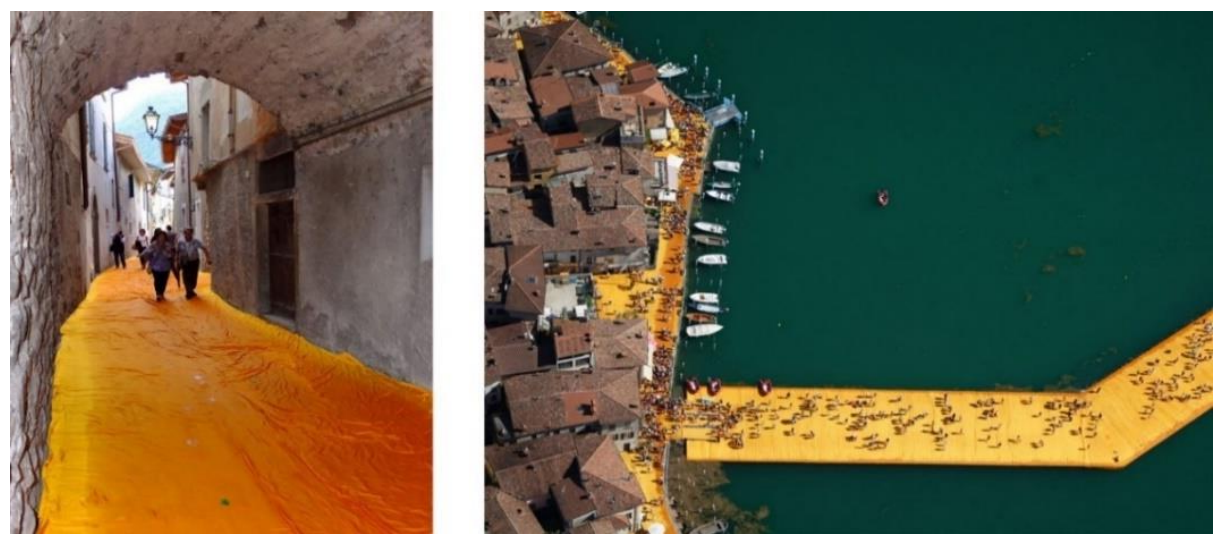

Şekil 2. Kumaş malzemenin iç sokaklara uzanarak, enstalasyonun kentle olan bütünlüğü sağlanmıştır [15].

Yapım aşamasında 220.000 tane polietilen küp kullanılmıştır. Küpler dalgıçlar yardımıyla suyun altından birbirine bağlanmış ve sonrasında 100.000 metrekarelik kumaşla kaplanmıştır. Hazırlık aşaması toplam üç ay süren enstalasyon sadece 16 gün boyunca sergilenmiştir. Sonrasında ise tüm malzemelerin geri dönüşüme gönderildiği bilinmektedir [15]. Bu anlamda tasarımcı Chisto "Biz kalıcılı̆̆ insanlarında belleklerinde sağlamak istedik [16]" sözleriyle geçici kamusal sanat ürünlerindeki zamansallığı farklı bir açıdan değerlendirmiştir.

\section{2 "1/4 Mile Arc" Enstalasyonu, Amerika- 2017}

Kaliforniyalı sanatçı Phillip K Smith'in ürettiği, 1/4 Mile Arc adlı interaktif sanat eseri 2017 yılında bir sert zemin olarak deniz ve kıyı arasında ara mekân olan plajda sergilenmiştir. Entalasyonda dalgaları kalıcı olarak yansıtmak için kıyı kıvrımını takip eden 250 adet ayna yerleştirilmiştir. Yerleştirilen aynalar tasarım prensibi olarak kıyıyla; okyanus, kumsal ve gökyüzünün gün içerisinde değişen 1şık-renk doğrultusundaki yansımalarının mekân algısının dönüşümüne dair bir ilişki kurmaktadır [18]. 

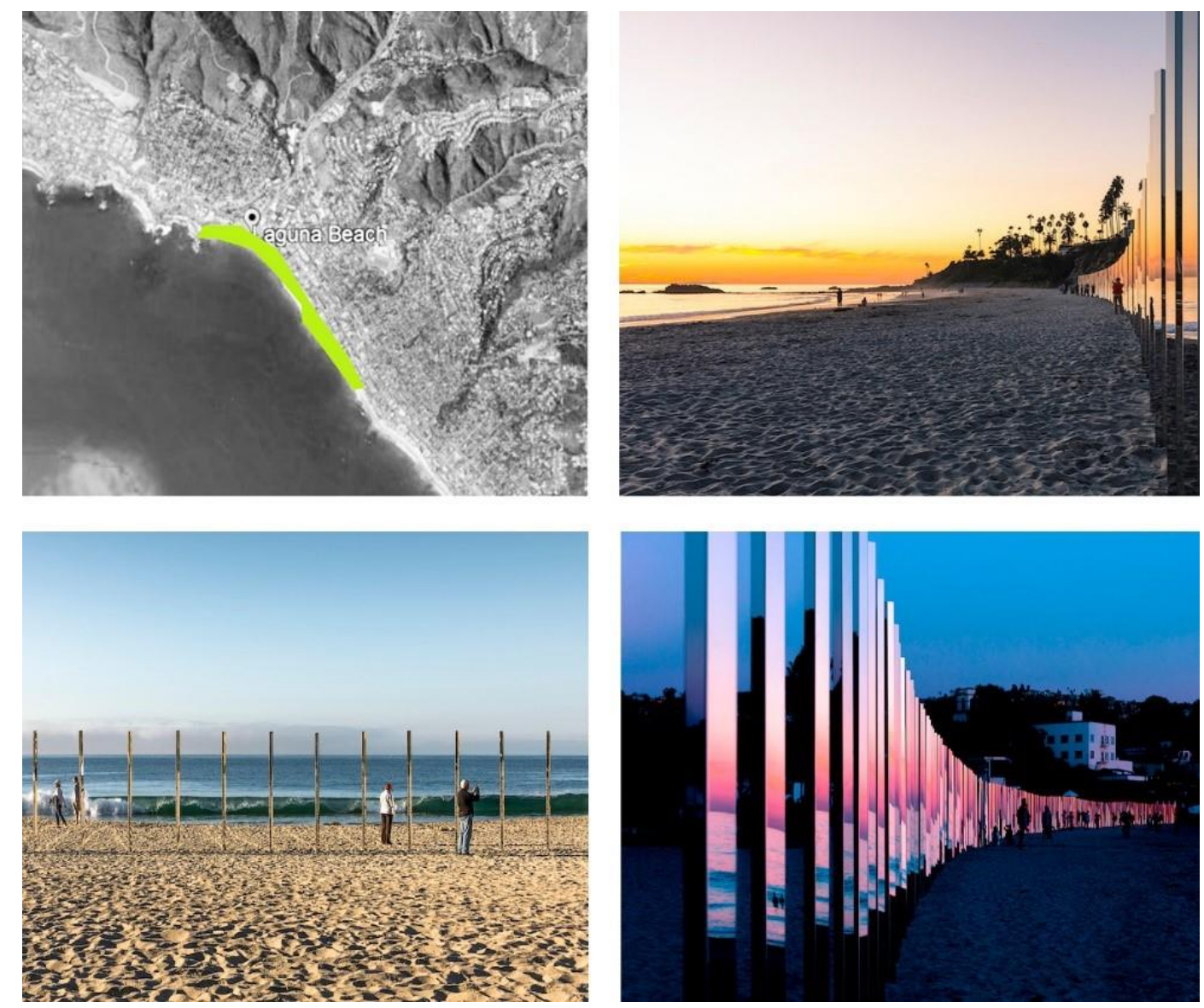

Şekil 3. '1/4 Mile Arc' Enstalasyonu ve gün 1şı̆̆ı döngüsü ile dönüşümü Amerika- 2017 [19].

Mekâna dinamizm, canlılık getiren kamusal sanat eserindeki aynalar gün içinde farklı tonlardaki güneş 1şıklarını yansıtarak plaj ile bütünleşmiştir. Yatay düzlemde uzayarak devam eden plaja 250 metre boyunca entegre olan aynalar plaja kattığı düşeylikle zıtlık oluşturmuştur. Bölge halkının birebir deneyimlediği enstalasyon geçici olarak sergilense de hafızalarda kalıcı olmuştur [19].

\section{3. "Three Matrix" Pavyonu, Amerika- 2017}

Mimarlık ve sanat tabanlı tasarım ofisi Sports, Kaliforniya şehri Santa Barbara için canlı bir işaret olarak 2017 yılında deniz üstünde mevcutta bulunan zeminde “Three Matrix” Pavyonu'nu sergilemiştir. Havanın estetik kalitesini mimarileştirmek amacıyla yapılan strüktür objeler canlı bir görsel ortamı vurgulamıştır. Camgöbeği, macenta, sarı renklerdeki grid sistemli tellerden oluşan üç platform, içindeki binlerce doğrusal öğe ile yoğun bir bulanıklık oluşturmuştur. Ayrıca strüktürler içinde barındırdığı boşluklarla çeşitli gölgeleme seçenekleri sunmuștur [20]. Basit geometri formlarındaki grid nesneler; kullanıcılar için oturma bankı, dinlenip uzandıkları mekân, hatta doğaçlama bir performans sahnesi oluşturan bir dizi olası yönelim sunmuştur. Kıyıdan uzanan platforma yerleştirilen tasarım kentsel dekor nesneleri olarak manzaraya cesur ve canlı bir kimlik kazandırmıştır. Kıyıdan uzakta konumlanan bu objeler bireylere aynı anda kıyıya, kente ve suya farklı açılardan bakma olanağı sunmuştur. 

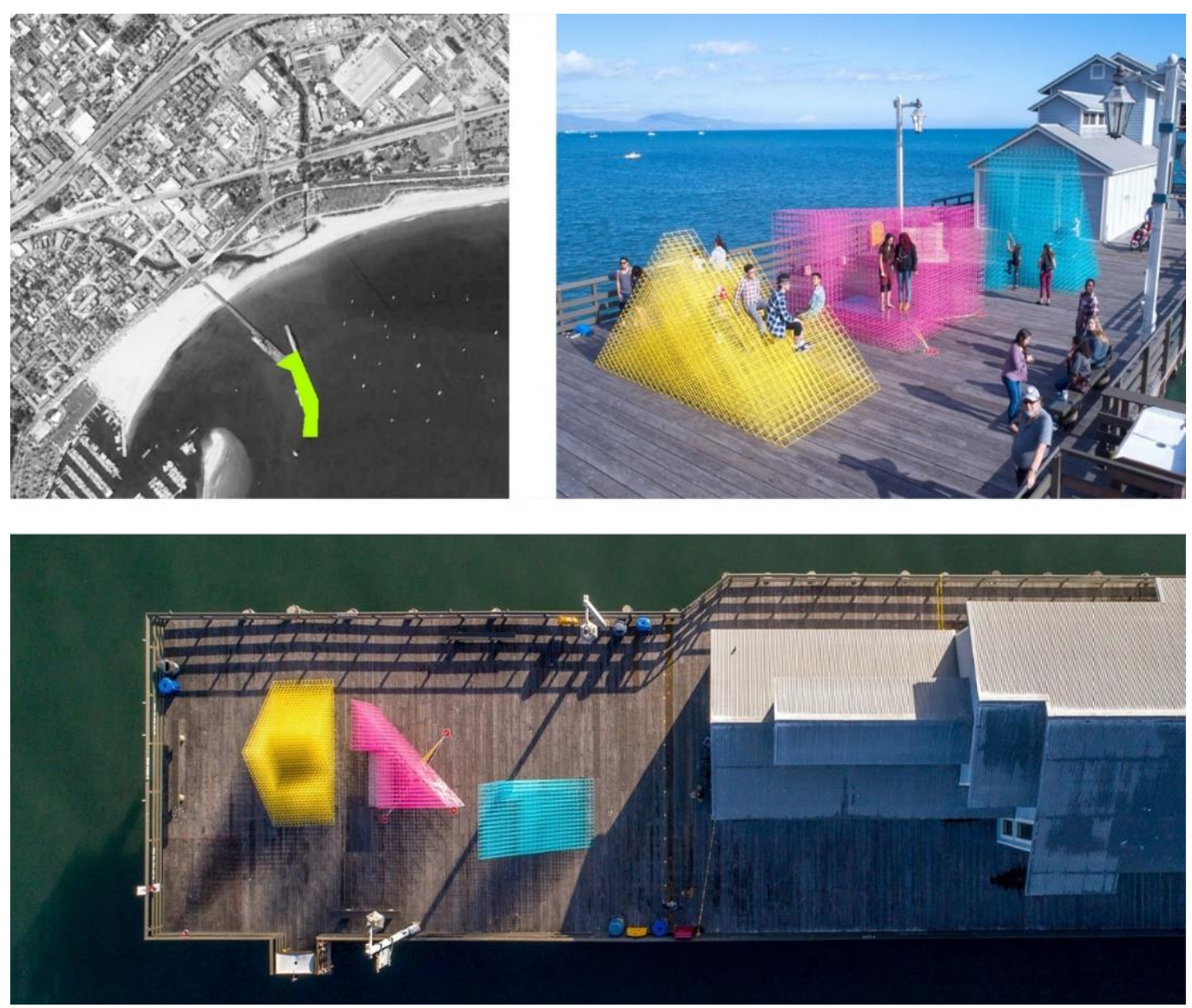

Şekil 4. 'Matrix' Pavyonu ve kıyı üzerindeki platformun kamusal sanatla dönüşümü Amerika- 2017 [20].

\section{4. "Triennale Brugge" Pavyonu, Hollanda- 2018}

İdeolojilerin ve yaşam biçimlerinin tehdit altında olduğu hızla değişen dünyamızda, 2018 Bruges Trienali bir soru öne sürüp "Bruges gibi tarihi bir şehir, artık hiçbir şeyin kesin olmadığı bir çağda ne kadar esnek, akıcı ve dayanıklı olabilir?"i sorgulamak istemiştir. Buna paralel olarak, şehrin kendi coğrafyasında yatan, suyla sarmalanmış ve örülmüş bir şehir olan Bruges, bu trienalde birçok kamusal sanat ürününün kendisine bir metafor olmuştur. Şehrin akışkanlığı ve sanatsal mirasının pitoresk enstalasyonlara dönüştüğü trienalde ziyaretçiler bu yaratıcı sürecin bir parçası olmuşlardır. SelgasCano tasarımı olan pavyonun ise ince, esnek, geçirgen örtüsüyle oluşturduğu renkli mekânda; suyun üzerinde katılımcılara farklı bir dünyaya giriyormuş hissiyatı vermesiyle trienalde sergilenen diğer kamusal sanat ürünlerinden ayrıştığı düşünülmektedir. 

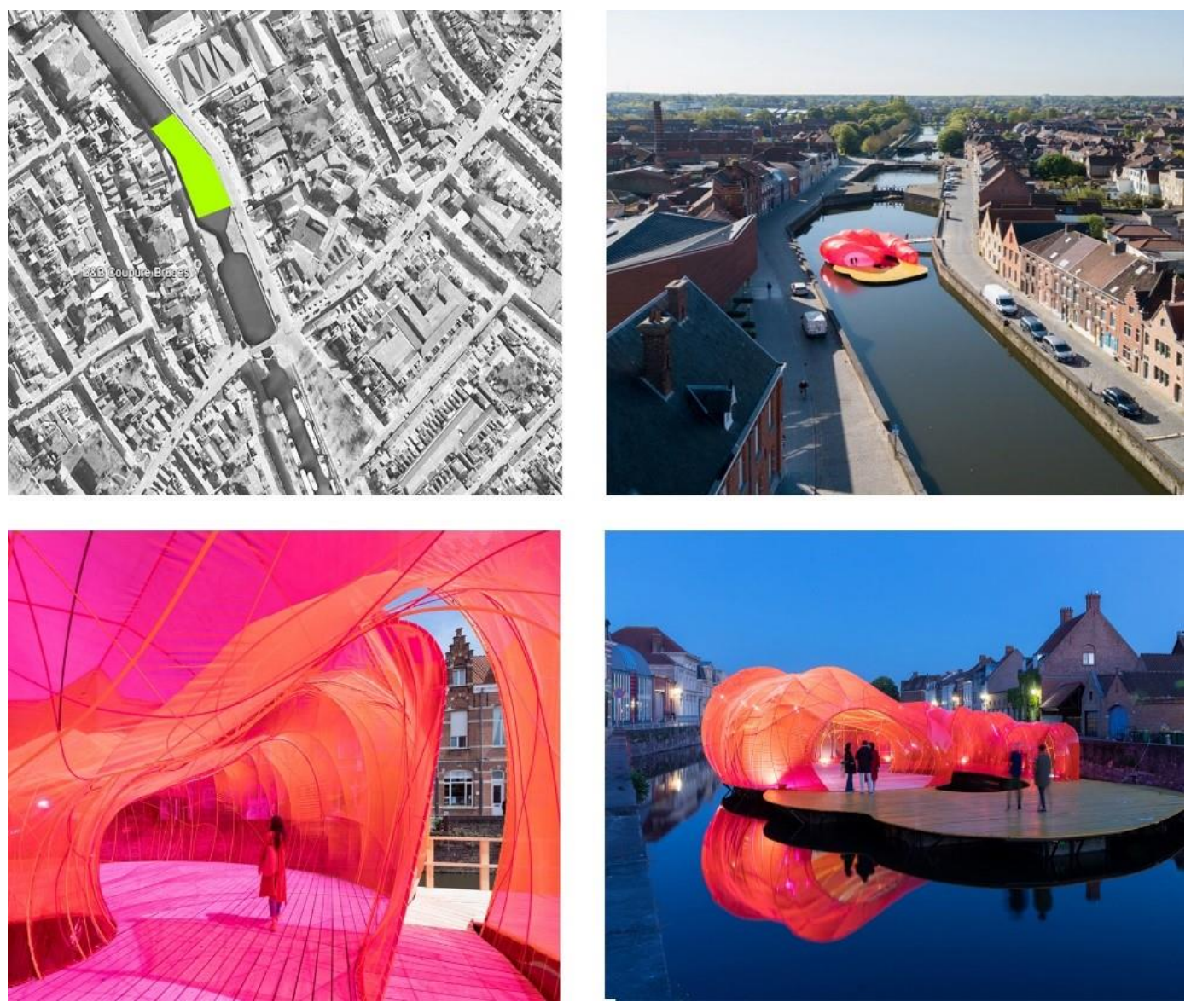

Şekil 5. ‘Triennale Brugge' Pavyonu, Hollanda- 2018 [21].

Tasarım ekibi, ziyaretçilerin dalış yapabilmeleri için bir yumuşak zemin olarak Coupure Kanalı'nda hareketli bir yüzen pavyon tasarlamıştır. Dış katman, 1şığın uzayda şakacı bir şekilde dolaşmasına izin vererek eski şehrin doğal algısını bozmuş ve fotoğrafçılar için bir ilham perisi görevi görmüştür [22]. Platform, yüzen bir enstalasyon olmasının yanı sıra, toplantı ve aktiviteler için bir alan olarak da hizmet vermiştir. Pembe-turuncu vinil ile çevrelenmiş çelik bir iskeletten oluşan pavyona sarı ahşap bir platform eklenerek ziyaretçilerin kanalda yüzmelerine ve dalış sporu yaparak su ögesi ile ilişski kurmalarına izin verilmiştir. Bu özellikleriyle pavyon bulunduğu kent özelinde bireylere interaktif deneyimler sunmuştur. Geçici kamusal sanat ürünü 1şı̆̆ın, renklerin oyunculuğu ve ziyaretçilerle etkileşim yaratma çabası ile dinamik ifadeye bürünerek hafizalardaki deneyimini sürdürmüştür [21].

\section{5. "Russian Creativity Week" Pavyonu, Rusya- 2020}

Eylül 2020'de, çeşitli kurum ve kuruluşların birçok temsilcisini bir araya getiren ilk Rus Yaratıcı Endüstriler Festivali kapsamında 14 adet tematik pavyon birimleri bir sert zemin olarak deniz kıyısında sergilenmiştir. Birimler konferans salonunun yanı sıra toplantı alanları, basın kabinleri ve bir bilgi merkezi içeren pavyonlar şeklinde oluşturulmuştur. Geniş bir izleyici kitlesinin ilgisini çeken ve geçici bir süre ile kıyıda konumlanan pavyonlar, düzenlenen konferanslar, eğitim programları, sergiler aracıllğıyla renklenmiştir. Çok yüzlü pavyonlar, yüksek tavanlı bir düzleme ve dersler için renkli bir iç mekâna sahip olmuştur. Biçim ve renkleriyle kıyıı kısa süreli dönüştüren pavyonlar salgın dönemindeki kurulumu nedeniyle sosyal mesafe ihtiyacı göz önünde bulundurularak her konferans salonunun maksimum 60 ziyaretçi kapasitesi 
bulunacak şekilde tasarlanmıştır [23]. Bu durum hem tasarım hem de mekânın kullanımının pandemi doğrultusunda şekillendiğini göstermektedir.
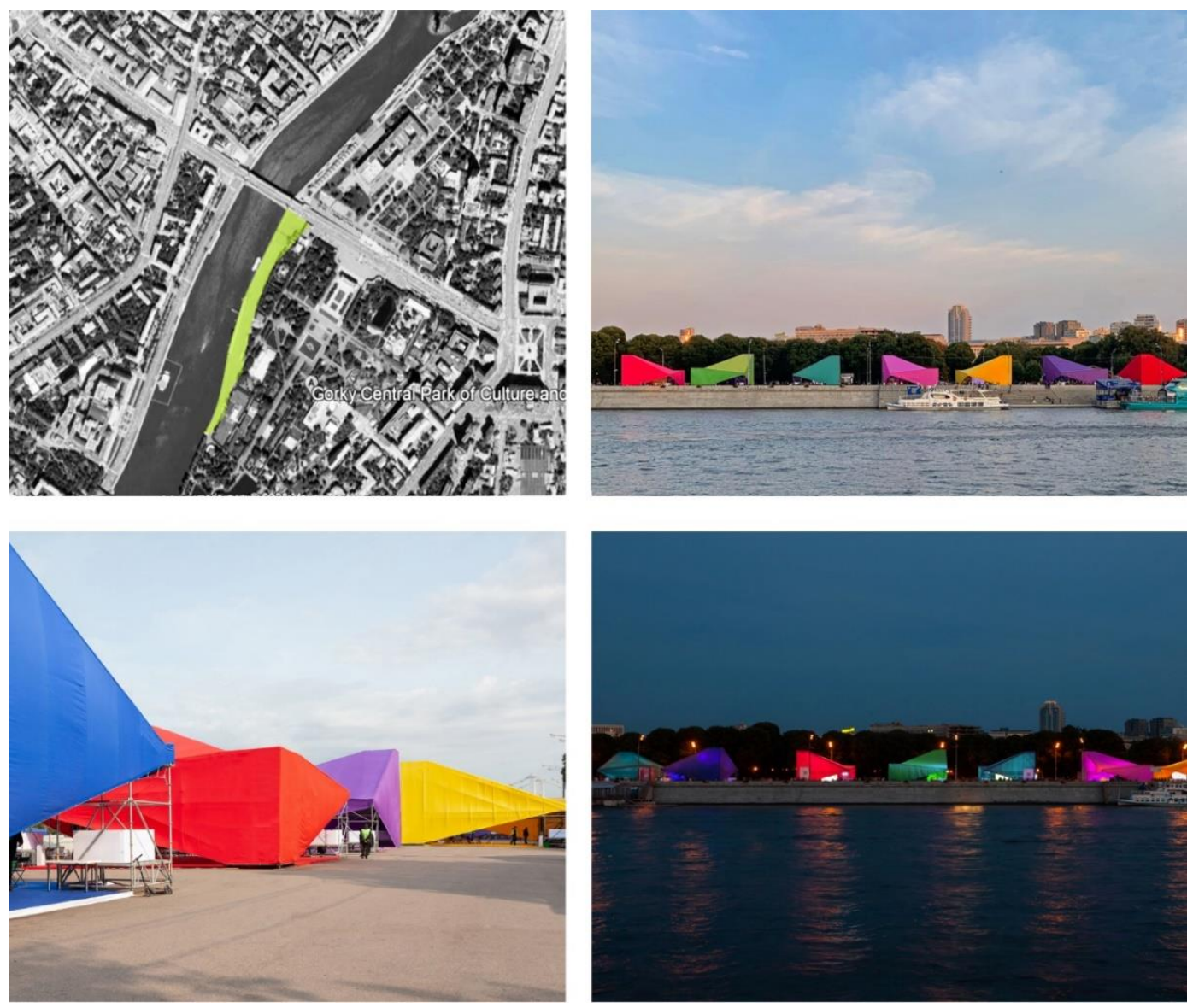

Şekil 6. 'Russian Creativity Week’ Pavyonu ve farklı renklerdeki pavyonların gündüz ve gece mekânı dönüştürmesi, Rusya- 2020 [24].

Çeşitli renklerde tasarlanmış olan pavyonlar geceleri canlı bir parıltı yayarak Gorky Park'ın manzarasını değiştirip başka bir atmosferi yaratmıştır. Aynı zamanda renk şeması pavyonlar arası navigasyonu basitleştirmiş ve pavyonlar arasındaki geçiş yolu, ziyaretçilerin konferans salonlarından geçmesine ve festivalin diğer bölgelerine kolayca ulaşmasına olanak tanımıştır [24].

Çalışma kapsamında incelenen su ögesi veya kıyı ile ilişkili "The Floating Piers” Enstalasyonu, "1/4 Mile Arc" Enstalasyonu, "Three Matrix" Pavyonu, "Triennale Brugge" Pavyonu ve "Russian Creativity Week" Pavyonu Sherwin Greene'nin belirlemiş olduğu kalite parametreleri [4] doğrultusunda aşağıdaki tablolar aracılığıly irdelenmiştir (Tablo 1). 
Tablo 1. İncelenen Kamusal Sanat Ürünlerinin Kentsel Kalite Paremetreleri Üzerinden Değerlendirilmesi

\begin{tabular}{|c|c|c|c|c|c|c|c|c|}
\hline \multirow[t]{5}{*}{ 'The Floating Piers' Enstalasyonu } & \multirow{5}{*}{$\begin{array}{c}\text { Enstalasyonun Kimlik Bilgisi } \\
\text { Mekan I Su üstü }\end{array}$} & \multicolumn{2}{|l|}{ İşlev } & Düzen & \multicolumn{2}{|c|}{ Kimlik } & \multicolumn{2}{|c|}{ Cazibe/Çekim } \\
\hline & & Bağlantı & ○ & Tutarlilik & Odak & - & Ölçek & \\
\hline & & Güvenlik & & Açıklık & Birlik & & Uygunluk & \\
\hline & & Konfor & & Devamlılık & Karakter & O & Canlilık & • \\
\hline & & Çeşitlilik & ○ & Denge & Özellik & & Uyum & \\
\hline \multirow[t]{5}{*}{ '1/4 Mile Arc' Enstalasyonu } & Enstalasyonun Kimlik Bilgisi & \multicolumn{2}{|l|}{ İşlev } & Düzen & \multicolumn{2}{|c|}{ Kimlik } & \multicolumn{2}{|c|}{ Cazibe/Çekim } \\
\hline & & Bağlantı & & Tutarlilik & Odak & - & Ölçek & \\
\hline & & Güvenlik & & Açıklık & Birlik & & Uygunluk & \\
\hline & & Konfor & & Devamlilık & Karakter & - & Canllık & $\bullet$ \\
\hline & Mekan | Kumsal & Çeşitlilik & ○ & Denge & Özellik & & Uyum & \\
\hline \multirow[t]{5}{*}{ 'Matrix' Pavyonu } & Pavyonun Kimlik Bilgisi & \multicolumn{2}{|l|}{ iş̧lev } & Düzen & \multicolumn{2}{|c|}{ Kimlik } & \multicolumn{2}{|c|}{ Cazibe/Çekim } \\
\hline & & Bağlantı & & Tutarllikk & Odak & - & Ölçek & \\
\hline & & Güvenlik & & Açıklık & Birlik & & Uygunluk & \\
\hline & Mekan I Sü̈stت̈ & Konfor & & Devamlilık & Karakter & - & Canlilik & ○ \\
\hline & & Çeşitlilik & ○ & Denge & Özellik & & Uyum & \\
\hline \multirow[t]{5}{*}{ 'Triennale Brugge' Pavyonu } & Pavyonun Kimlik Bilgisi & \multicolumn{2}{|l|}{ işlev } & Düzen & \multicolumn{2}{|c|}{ Kimlik } & \multicolumn{2}{|c|}{ Cazibe/Çekim } \\
\hline & & Bağlantı & & Tutarlilik & Odak & - & Ölçek & \\
\hline & & Güvenlik & & Açiklık & Birlik & & Uygunluk & \\
\hline & Mekan I Su üstü & Konfor & & Devamlılık & Karakter & O & Canlilik & - \\
\hline & & Çeşitlilik & ○ & Denge & Özellik & & Uyum & \\
\hline \multirow[t]{5}{*}{ 'Russian Creativity Week' Pavyonı } & Pavyonun Kimlik Bilgisi & \multicolumn{2}{|l|}{ işlev } & Düzen & \multicolumn{2}{|l|}{ Kimlik } & \multicolumn{2}{|c|}{ Cazibe/Çekim } \\
\hline & 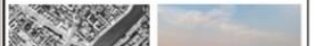 & Bağlantı & & Tutarllilik & Odak & - & Ölçek & \\
\hline & 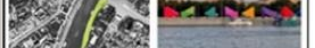 & Güvenlik & & Açıklık & Birlik & & Uygunluk & \\
\hline & Mekan | Kıуı & Konfor & & Devamlılık & Karakter & ○ & Canlilik & \\
\hline & & Çeşitlilik & 0 & Denge & Özellik & & Uyum & \\
\hline
\end{tabular}

İncelenen tablolarda su ile ilişkili olan ksamusal sanat ürünleri kalite parametreleri bakımından değerlendirilecek olursa, ilk olarak $\dot{I s ̧ s}_{\text {lev }}$ parametresinin dört kamusal sanat ürününde de çeşitlilik sağladığ1, aynı zamanda "The Floating Piers"da bağlantı noktası oluşturduğu da görülmektedir.Bir diğer kalite 
parametresi olan Düzen'in tutarlılık, açıklık, devamlılık, denge anlamında herhangi bir özelliği taşımadığı görülmüş̧ür. Bu durum sanatın bu tarz parametreleri vaat etmemesi ve sınırlar anlamında özgür olmasından kaynaklanmaktadır. Kimlik parametresi doğrultusunda incelenen kamusal sanat ürünlerinin bulunduğu kentsel mekânda bir odak noktası oluşturduğu, o noktayı çekici hale getirdiği ve o mekâna bir karakter kattığ 1 düşünülmektedir. Bir diğer kalite parametresi olan Cazibe/Çekim noktası bakımından ise dört kamusal sanat ürününün de bulunduğu mekâna canlılık kattığı görülmüştür.

\section{ANTALYA-KONYAALTI SAHILININ KAMUSAL SANAT BAĞLAMINDA İRDELENMESI}

Değişim kaçınılmaz bir şekilde kentlerde, teknolojide, inşaatta, ulaşım ve sağlı gibi alanlarda kendini göstermektedir ve geleceği yönlendirmektedir. Kentlerdeki dönüşümü harekete geçiren, hızlandıran belli başl1 aktörler söz konusudur. Bu aktörler; sosyal, kültürel, idari, siyasi, değişimlere bağlı olarak kenti şekillendirebilmektedir. Kentleri biçimlendiren bu aktörler mimari ve kentsel dönüşümün; özellikle "kıyı ortamında" ortaya çıkmasını sağlamaktadır. Kıyı, yerleşimler için önemli bir sınır, aynı zamanda bir etkileşim [25] ve iletişim alanıdır. Yumuşak bir zemin olarak su ögesi ve bu ögenin sert zemin olan kentle ilişkisini sağlayan kıyılar, kentlerdeki planlamada ara mekân olarak önemli bir rol üstlenmektedir. Bu doğrultuda Antalya-Konyaaltı sahili de bir yarışma projesi aracılığıyla 2018 yılında yeniden düzenlenmiştir [26].

Tablo 2. Konyaaltı Sahili kamusal mekân düzenlemeleri, Balçık (2020) arşivinden.

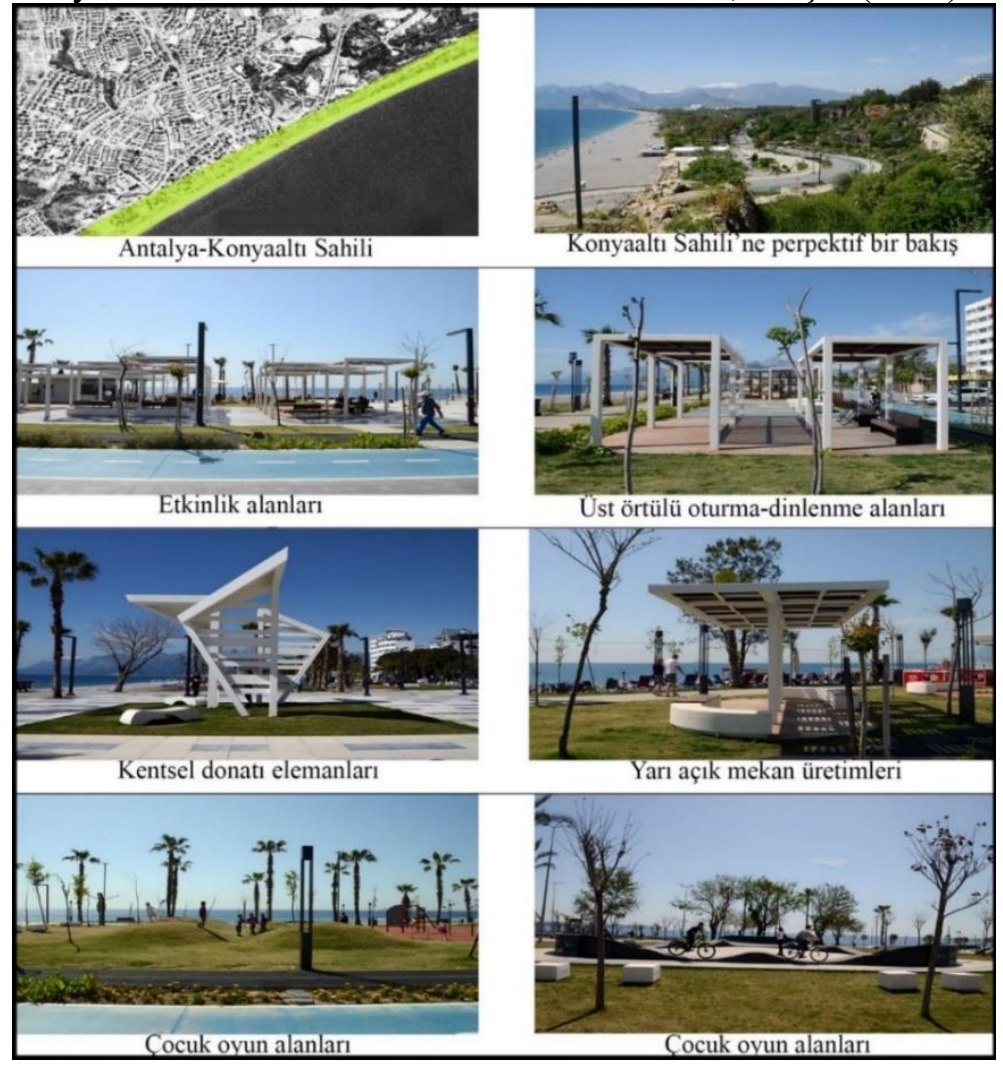

Kamusal sanat olarak değerlendirilebilecek olan kent mobilyalarıyla düzenlemeler kıyıya yeni bir soluk getirmiştir. Antalya kent kimliğini şehrin sahip olduğu en önemli değer olan deniz kıyısı üzerinden yeniden güçlendirme hedefiyle yola çıkan proje kentsel kıyıyı her türden kullanıcı için erişilebilir ve algılanabilir 
kılmaya çalışmıştır. Kıyı kullanımını zenginleştiren uygulamalar kıyıyı rekreasyon, spor ve kültür faaliyetleri ile çoklu ve karma kullanımlı yeniden ișlevlendirmiștir. Kıyı șeridi boyunca denize paralel mekânsal sürekliliğe olanak verecek yatay kent mobilyaları odak alanlarda ve dikey bağlantı güzergâhlarında farklı fiziksel tasarım kurguları çerçevesinde sistemli tipolojik farklılașmaları sağlamıștır [26]. Kıyı kotu ile ilişki kuran üst örtülü oturma-dinlenme mekânları, yarı açık mekân üretimleri, etkinlik alanları, su aktivite alanları çocuk oyun alanları, kentsel donatı elemanları şeklinde çeşitlenen parametrelere sahip olan uygulamalar kentin kıyı kullanımı açısından zenginliğini göstermektedir [27].

Tablo 3. Antalya-Konyaaltı Sahili’ndeki kamusal sanat ürünlerinin kullanım parametreleri

\begin{tabular}{|c|c|c|}
\hline \multirow{2}{*}{ PARAMETRELER } & \multicolumn{2}{|c|}{ KULLANIM TÜRÜ } \\
\cline { 2 - 3 } & Kıyı (Sert Zemin) & Su (Yumuşak Zemin) \\
\hline üst örtülü oturma dinlenme mekanları & 0 & - \\
\hline yarı açık mekan üretimleri & 0 & - \\
\hline etkinlik alanları & - & - \\
\hline çocuk oyun alanları & 0 & - \\
\hline kentsel donatı elemanları & 0 & - \\
\hline
\end{tabular}

Mevcut parametrelerin kıyı düzenlemeleri ile ilgili birçok veriyi sağladığı görülmüştür. Kıyı (sert zemin) kullanımları çeşitlenip değişkenlik gösterirken, su ögesi anlamında kullanım olarak eksiklikler görülmüştür. Yerin kalitesi ile yaşam kalitesi arasında bağ kurulmaya çalışıldığ 1 ve bu doğrultuda sahilin çeşitli kamusal sanat ürünleriyle yeniden düzenlendiği görülmüştür. Konyaaltı sahili Sherwin Greene [4] tarafindan belirlenen parametreler doğrultusunda değerlendirilmiştir (Tablo 4).

Tablo 1. Antalya-Konyaaltı Sahili'nin Kalite Parametreleri Üzerinden Değerlendirilmesi

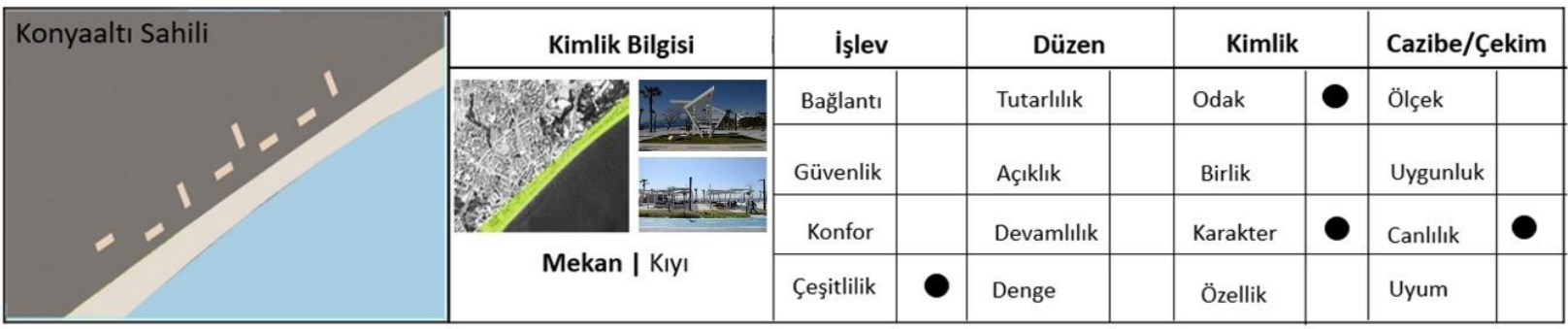

Konyaaltı sahilindeki kamusal sanat düzenlemelerinde $\dot{I}_{s ̧ l e v}$ parametresinin çeşitlilik anlamında zengin olduğu görülmektedir. Kimlik parametresi ele alındığında, mekânda birden fazla kamusal sanat ürünü olduğu için odak noktaları anlamında tek bir noktadan ziyade bölünmelere uğradığı sonucuna varılmaktadır. Cazibe/Çekim parametresi ise Konyaaltı Sahili'ne canlılık özelliği kazandırmıştır. Bu doğrultuda Konyaaltı sahili için kıyıyla kurulan ilişki bakımından çeşitlilik sağladığı söylenebilir.

\section{SONUÇ}

Kıyı tasarımları bireylerin su ile iletişiminde etkin rol oynamaktadır. Kullanıcıların suya erişimleri, su ile ilişkisi tasarımın tanıdığı imkanlarla sağlanmaktadır. Dokunma, seyretme veya işitme eylemleri su ile iletişim kurmanın duyusal yöntemleridir. Kamusal sanat ürünleri bu eylemler aracılığıyla bulundukları mekânların deneyimlenmesini ve algılanmasını sağlamaktadır. Su ile ilişki kuran, kimi zaman ona dokunan, 
onu çevreleyen kimi zamansa su ile arasına mesafe koyup onu uzaktan seyrederek kullanımı çeşitlendiren kamusal sanat ürünleri bu bağlamda oldukça değerli görülmektedir. Çalışma kapsamında incelenen "The Floating Piers" Enstalasyonu, "1/4 Mile Arc" Enstalasyonu, "Three Matrix" Pavyonu, "Triennale Brugge" Pavyonu, "Russian Creativity Week" Pavyonu kamusal sanat ürünleri Sherwin Greene (1992)'nin belirlemiş olduğu kentsel mekanda kalite parametreleri doğrultusunda irdelenmiştir. Kıyı ve su ile ilişki kuran bu tasarımlar kalite parametreleri bakımından olumlu görülmesiyle beraber geçici süreyle sergilenmeleri de bu durumu desteklemektedir. Bu zamansallık durumu kamusal sanat ürünlerinin konumlandığı kent mekanlarına yeni bir soluk getirdiğini göstermektedir. Öyle ki; belirli bir süreyle sergilenen bu tasarımlar hem kentliye hem kent dışından bireylere davetkar nitelikte olmaktadır. Bu durum ise tasarımı görmek için farklı kent ve hatta farklı ülkelerden gelen bireylerin o sanat ürününün bulunduğu kente turizm ve ekonomik açıdan katkı sağladığı anlamına gelmektedir.

Antalya Konyaaltı Sahili'ndeki kamusal sanat ürünlerinin kentsel mekanda kalite parametreleri doğrultusunda elde edilen olumlu özelliklerinin yanında su ile temas etme, suya dokunma gibi özellikler açısından geri planda kaldığı görülmektedir. Bu bağlamda öneri olarak yumuşak ve sert zeminin kesişerek, su ögesi ile doğrudan ilişki sağlayacak, su üzerinde kurulacak bir bağlantı platformuyla kente geçici şekilde hizmet verebilecek bir kamusal sanat ürününün tasarlanabileceği düşünülmektedir. Böylesi bir tasarım hem kıyıya ve su ögesine hem de kente yeni bir tanım getirecektir. Bu kapsamda Antalya-Konyaaltı sahilindeki kıyı kullanımının su ile ilişkilenebileceği ara yüz tasarımları önerilmektedir. Özellikle yarışma projelerinin önem kazandığı günümüzde bir turizm kenti olan Antalya için her yıl bir kamusal sanat yarışması ile tekrarlanacak, dinamizm sağlayacak, su ve kıyı ile ilişki kuracak geçici bir tasarım; kente turizm, ekonomik ve sosyal açıdan katkı sağlayacaktır. Bir nevi eşik mekân olarak nitelendirilebilecek su üstü kullanımlarının kent panoramasına katkı sunacağı, kentin mevcut yüzüne yeni bir tanım getireceği ve geçicilik durumunun belleksel anlamda bireylere katkı sağlayacağına inanılmaktadır. 


\section{REFERANSLAR}

[1] Hayden, D. (1995). The Power of Place: Urban Landscapes as Public History. Cambridge Massachusetts, London: The Mit Press.

[2] Hanru, H. (2007). "Sürekli Yenilenen Kamusallığı Kurmak ve Kolektif Eylem." P. Tan, \& S. Boynik (Dü) içinde, Olasıllklar, Duruşlar, Müzakere Güncel Sanatta Kamusal Alan Tartışmaları; 139-142. İstanbul: Bilgi Üniversitesi Yayınları.

[3] İnceoğlu, M., Aytuğ, A. (2009). "Kentsel Mekânda Kalite Kavramı." Megaron; 131-146.

[4] Greene, S. (1992). "Cityshape: Communicating and Evaluating Community Design, American Planning Association." Journal of the American Planning Association, 58(2); 177-189.

[5] Aydın, R. E. (2015). "Kamusal Alan ve Sanat" Konusuna Eleştirel Bir Yaklaşım. https://ronyaemel.wordpress.com/2015/04/07/kamusal-alan-ve-sanat-konusuna-elestirel-bir-yaklasim/ Erişim Tarihi: 08.02.2020

[6] Langer, S. K. (2012). Sanat Problemleri. (F. Korur, Çev.) Topkapı / İstanbul: Mitos-Boyut TEM Yapım Yayıncilik.

[7] Eco, U. (2001). Açık Yapıt. Alexander Calder'in Açık Yapıtları. (M. Bulat, S. Bulat, \& B. Aydın, Dü) İstanbul.

[8] Reiss, J. H. (1999). "From Marginto Center: The Spaces of Installation Art." Cambridge: MIT Press.Mow, V. C., Gu, W. Y. and Chen, F. H. (2005).

[9] Bayram, B. (2007). Kamusal Mekân Kalitesinin Yükseltilmesinde Yöntemler ve Kamusal Sanatın Rolü. Yüksek Lisans Tezi; 69.

[10] Carr, S., Francis, M., Rivlin, L. G., and Stone, A. M. (1992). Public Space. Cambridge: Cambridge University Press.

[11] Ercan, M. (2013). "Kamusal Sanatın 'Kamusallı̆̆ı’': Erişim, Aktör, Fayda Yaklaşımı." İdealkent Dergisi (10); 220-255.

[12] Gökçen, Ş. (2018). "Kamusal Sanat ve Kültür Eksenli Kentsel Dönüşüm." Journal of Interdisciplinary and Intercultutal Art, 3(6).

[13] Çelik, K. (2015). "Kıуı Alanlarının Planlanmasında Kıyı Kenar Çizgisinin Önemi." Küresel Mühendislik Çalışmaları Dergisi, 2(1); 36-43

[14] Read, H. (1960). Sanatın Anlamı. Ankara: Türk Tarih Kurumu Basımevi.

[15] https://christojeanneclaude.net/artworks/the-floating-piers/

[16] Baal-Teshuva, J. (2016). Christo and Jeanne-Claude. Cologne, Germany: Taschen.

[17] Kılınç, C. (2020). Kamusal Sanatın Deneyselliği Üzerine Bir İrdeleme. Yüksek Lisans Tezi. Eskişehir.

[18] Howarth, D. (2016). Phillip K Smith III's Quarter Mile Arc reflects sea and sky at Laguna Beach. dezeen: https://www.dezeen.com/2016/12/19/phillip-k-smith-iii-quarter-mile-arc-reflects-sea-sky-laguna-beachcalifornia-design-installation/ Erişim Tarihi: 13.03.2021

[19] http://www.fubiz.net/2017/01/11/majestic-installation-made-of-250-mirrors-in-california/ 
[20]https://worldarchitecture.org/architecturenews/cvcch/three_matrix_pavilions_by_sports_are_scattered_in_di fferent_parts_of_santa_barbara.html

[21]https://www.archdaily.com/894445/selgascano-adds-a-splash-of-color-to-the-bruges-triennale-with-newinstallation?ad_source=search\&ad_medium=search_result_all

[22] Stouhi, D. (2018). SelgasCano Adds a Splash of Color to the Bruges Triennale with New Installation. Archdaily: https://www.archdaily.com/894445/selgascano-adds-a-splash-of-color-to-the-bruges-triennalewith-new-installation Erişim Tarihi: 13.03.2021

[23]Pintos, P. (2020). Pavilion Russian Creativity Week 2020 / SKNYPL. Archdaily: https://www.archdaily.com/951848/pavilion-russian-creativity-week-

2020sknypl?ad_source=search\&ad_medium=search_result_all Erişim Tarihi: 13.03.2021

[24]https://www.archdaily.com/951848/pavilion-russian-creativity-week-2020sknypl?utm_medium=email\&utm_source=ArchDaily\%20List\&kth=4,733,698

[25] Erdoğmuş, B. (2012). "Bir Kıyı Yerleşmesinde Kimlik Dönüşümü: Tarihsel Süreç İçinde Karşıyaka'nın (İzmir) Kıyı Kullanımında Gözlenen Değişimler." Ege Coğrafya Dergisi.

[26] http-6: http://www.arkiv.com.tr/proje/1-odul-konyaalti-sahili-mimari-ve-kiyi-duzenlemesi-fikir-projesiyarismasi $/ 3995$

[27] Balçık, S., İnceoğlu, M. (2020). "Yenilenen Antalya / Konyaalti Kiyi Düzenlemesinin Alan Kullanim Çeşitliliği Açisindan Değerlendirilmesi." Akdeniz Üniversitesi Sosyal Bilimler Enstitüsü Dergisi (AKSOS) (8); 57-70. 